\title{
Excitatory effect of ATP on rat area postrema neurons
}

\author{
Masaru Sorimachia $\cdot$ Minoru Wakamoria $\cdot$ Norio Akaikeb
}

Received: 11 October 2005 / Accepted: 26 January 2006 / Published online: 30 May 2006

(C) Springer Science + Business Media B.V. 2006

\begin{abstract}
ATP-induced inward currents and increases in the cytosolic $\mathrm{Ca}^{2+}$ concentration $\left([\mathrm{Ca}]_{\text {in }}\right)$ were investigated in neurons acutely dissociated from rat area postrema using whole-cell patch-clamp recordings and fura-2 microfluorometry, respectively. The ATPinduced current $\left(I_{\mathrm{ATP}}\right)$ and $[\mathrm{Ca}]_{\text {in }}$ increases were mimicked by 2-methylthio-ATP and ATP- $\gamma \mathrm{S}$, and were inhibited by $\mathrm{P} 2 \mathrm{X}$ receptor (P2XR) antagonists. The current-voltage relationship of the $I_{\mathrm{ATP}}$ exhibited a strong inward rectification, and the amplitude of the $I_{\text {ATP }}$ was concentration-dependent. The $I_{\text {ATP }}$ was markedly reduced in the absence of external $\mathrm{Na}^{+}$, and the addition of $\mathrm{Ca}^{2+}$ to $\mathrm{Na}^{+}$-free saline increased the $I_{\text {ATP. }}$ ATP did not increase $[\mathrm{Ca}]_{\text {in }}$ in the absence of external $\mathrm{Ca}^{2+}$, and $\mathrm{Ca}^{2+}$ channel antagonists partially inhibited the ATP-induced $[\mathrm{Ca}]_{\text {in }}$ increase, indicating that ATP increases $[\mathrm{Ca}]_{\text {in }}$ by $\mathrm{Ca}^{2+}$ influx through both P2XR channels and voltage-dependent $\mathrm{Ca}^{2+}$ channels. There was a negative interaction between P2XR- and nicotinic ACh receptor (nAChR)-channels, which depended on the amplitude and direction of current flow through either channel. Current occlusion was
\end{abstract}

M. Sorimachia $(\bowtie) \cdot$ M. Wakamoria $\cdot$ N. Akaikeb Department of Physiology, Graduate School of Medical and Dental Sciences, Kagoshima University, Kagoshima, 890-8520, Japan

e-mail: ciliary@m.kufm.kagoshima-u.ac.jp

Research Division for Life Sciences,

Kumamoto Health Science University, Kumamoto, 861-5598, Japan observed at $V_{\mathrm{h}} \mathrm{s}$ between -70 and $-10 \mathrm{mV}$ when the $I_{\mathrm{ATP}}$ and ACh-induced current $\left(I_{\mathrm{ACh}}\right)$ were inward, but no occlusion was observed when these currents were outward at a $V_{\mathrm{h}}$ of $+40 \mathrm{mV}$. The $I_{\mathrm{ATP}}$ was not inhibited by co-application of ACh when the $I_{\mathrm{ACh}}$ was markedly decreased either by removal of permeant cations, by setting $V_{\mathrm{h}}$ close to the equilibrium potential of $I_{\mathrm{ACh}}$, or by the addition of $d$-tubocurarine or serotonin. These results suggest that the inhibitory interaction is attributable to inward current flow of cations through the activated P2XR- and nAChRchannels.

Keywords ATP A ACh - cytosolic $\mathrm{Ca}^{2+}$ concentration . Fura-2 microfluorometry - negative interaction between nicotinic and $\mathrm{P} 2 \mathrm{X}$ channels - whole-cell patch-clamp recording

\section{Introduction}

The rat area postrema (AP) is a medullary circumventricular organ located in the hindbrain at the level of the obex, with a dense vascular supply devoid of a blood-brain barrier. The lack of a blood-brain barrier makes the AP ideally placed to act as a chemosensitive trigger zone involved in the control of vomiting in response to circulating emetic substances (Borison [1,2]). Neurons in the AP are also responsive to changes in osmolarity or sodium concentration (Franchini et al. [3]), and can be activated by circulating vasoactive peptides such as angiotensin II (Fink et al. [4]), and arg-vasopressin (Undesser et al. 
[5]). Anatomical studies have revealed that the AP sends dense efferent projections to the nucleus tractus solitarius, parabrachial nucleus, nucleus ambiguus, and the dorsal motor nucleus of the vagus, and receives afferent inputs from the hypothalamic paraventricular and dorsomedial nucleii, and from the caudal nucleus tractus solitarius (Morest [6]; Kooy and Koda [7]; Shapiro and Miselis [8]). Thus, the AP is not only capable of responding to circulating hormones, but is also anatomically well situated to regulate a range of other central neurons, including those important in cardiovascular control (Sun and Spyer [9]). The low intrinsic firing rates of AP neurons in vivo (Papas et al. [10]) suggests that understanding and modulating excitatory inputs to AP could be particularly important in the functional output of AP neurons. A number of transmitters can evoke excitatory currents in the AP. Inward currents and increases in cytosolic $\mathrm{Ca}^{2+}\left([\mathrm{Ca}]_{\text {in }}\right)$ via nonNMDA-glutamate receptors have been reported in rabbit and rat AP neurons, respectively (Jahn et al. [11]; Hay and Lindsley [12]). Our preliminary reports indicated that ATP also induces inward currents and $[\mathrm{Ca}]_{\text {in }}$ increases via the activation of $\mathrm{P} 2 \mathrm{X}$ receptor (P2XR) in isolated rat AP neurons (Sorimachi et al. $[13,14])$. In addition, pre- and post-synaptic nicotinic ACh receptors (nAChR) have been demonstrated in the AP in rat brain slices (Funahashi et al. [15]), and we have recently reported the presence of nAChRs in dissociated rat AP neurons (Sorimachi and Wakamori [16]). During that study, we also noticed that many of these AP neurons also responded to ATP, which has prompted us to further investigate ATP responses in AP neurons, and potential interactions between nAChR and P2XR responses. In a variety of different peripheral neurons, including sympathetic neurons of bullfrog (Akasu and Koketsu [17]), rat (Nakazawa et al. [18]), and guinea-pig (Searl et al. [19]), cultured guinea-pig enteric and submucosal neurons (Zhou and Galligan [20] Barajas-Lopez et al. [21]), a negative interaction between P2XR- and $\mathrm{nAChR}$ responses has been reported. Such an interaction has also been observed for recombinant $\mathrm{P} 2 \mathrm{X} 2$ and $\alpha 3 \beta 4 \mathrm{nAChR}$ channels in Xenopus oocytes and HEK cells (Khakh et al. [22, 23]; Boue-Grabot et al. [24]), where it has been recently suggested that this results from direct physical interactions between co-localized receptors (Khakh et al. [23]). In this study we more fully describe P2XR responses in AP neurons, demonstrate cross-inhibition between P2XRs and nAChRs and characterize some of the features of this crossinhibition.

\section{Experimental procedures}

\section{Preparation of AP neurons}

The study was approved by the Committee on Animal Experimentation, Kagoshima University. Wistar rats (13-18 days-old) were anaesthetized with ether and decapitated. The brain was quickly removed from the skull and placed in ice-cold HEPES-buffered saline containing $150 \mathrm{mM} \mathrm{NaCl}, 5 \mathrm{mM} \mathrm{KCl}, 2 \mathrm{mM} \mathrm{CaCl}_{2}$, $1 \mathrm{mM} \mathrm{MgCl}, 10 \mathrm{mM}$ HEPES and $5.5 \mathrm{mM}$ glucose. The $\mathrm{pH}$ of the saline solution was adjusted to 7.4 by adding tris (hydroxymethyl) aminomethane. The brain was sliced at a thickness of $400 \mu \mathrm{m}$ with a microslicer (DTK-1000, Dosaka, Kyoto, Japan), and the slices were kept in bicarbonate-buffered saline bubbled continuously with $95 \% \mathrm{O}_{2}-5 \% \mathrm{CO}_{2}$ at room temperature $\left(21-26{ }^{\circ} \mathrm{C}\right)$. The bicarbonate-buffered saline contained $120 \mathrm{mM} \mathrm{NaCl}, 5 \mathrm{mM} \mathrm{KCl}, 2 \mathrm{mM} \mathrm{CaCl}_{2}, 1 \mathrm{mM} \mathrm{MgCl}_{2}$, $20 \mathrm{mM} \mathrm{NaHCO}_{3}, 2 \mathrm{mM} \mathrm{KH}_{2} \mathrm{PO}_{4}$ and $5.5 \mathrm{mM}$ glucose. Following 30-60 min incubation, the slices were treated with pronase $(0.2 \mathrm{mg} / \mathrm{ml})$ in bicarbonate-buffered saline for $20 \mathrm{~min}$ at $33{ }^{\circ} \mathrm{C}$, followed by incubation for $30 \mathrm{~min}$ with bicarbonate-buffered saline containing thermolysin $(0.12-0.15 \mathrm{mg} / \mathrm{ml})$. The bilateral AP regions were identified with a binocular microscope (Zeiss, Germany), and were cut out using the tip of an injection needle, and subsequently mechanically triturated with fire-polished glass pipettes of decreasing diameters. Dissociated neurons were placed on to the bottom of $35 \mathrm{~mm}$ culture dishes (Falcon, USA) for electrophysiological recordings, or on to glass coverslips (Matsunami, Japan) coated with poly-L-lysine for $[\mathrm{Ca}]_{\text {in }}$ measurements.

\section{Electrophysiological recordings}

Electrical measurements were done using the wholecell patch-clamp recording configuration under voltage-clamp conditions. Patch pipettes were fabricated from borosilicate glass tubes in five or six stages using a pipette puller (Model P-97, Sutter Instrument, San Rafael, CA, USA). The resistance between the recording electrode filled with the internal solution, and the reference electrode in the external solution, was 3$6 \mathrm{M} \Omega$. Ionic currents were measured, and voltages controlled, using a patch-clamp amplifier (EPC-9, Heka, Darmstadt, Germany). All experiments were carried out at $24-26^{\circ} \mathrm{C}$. Culture dishes were placed on an inverted microscope (TE200, Nikon, Japan), and drugs were rapidly applied to single cells using a Ytube perfusion device. The internal solution (patch 
pipette solution) contained $70 \mathrm{mM} \mathrm{K}$-gluconate, 50 $\mathrm{mM} \mathrm{KCl}, 10 \mathrm{mM} \mathrm{NaCl}, 0.5 \mathrm{mM} \mathrm{CaCl} 2,3 \mathrm{mM} \mathrm{MgCl}_{2}$, $10 \mathrm{mM}$ HEPES, $10 \mathrm{mM}$ EGTA, and $2 \mathrm{mM}$ ATP. The $\mathrm{pH}$ was adjusted to 7.2 with $\mathrm{KOH}$. For measuring current-voltage $(I-V)$ relationships, a Cs-based internal solution was employed, which contained $98 \mathrm{mM}$ $\mathrm{CsOH}, 40 \mathrm{mM} \mathrm{CsCl}, 98 \mathrm{mM}$ aspartate, $2 \mathrm{mM} \mathrm{MgCl}_{2}, 5$ mM HEPES, $5 \mathrm{mM}$ EGTA, and $2 \mathrm{mM}$ ATP. $\mathrm{pH}$ was adjusted to 7.2 with $\mathrm{CsOH}$. The external solution was the HEPES-buffered saline, pH7.4, described above. When $N$-methyl-D-glucamine $\left(\mathrm{NMDG}^{+}\right)$or sucrose was substituted for external $\mathrm{Na}^{+}$or $\mathrm{NaCl}$, respectively, the osmolarity of the solution was kept constant as measured using an osmometer (Vogel OM801, Germany). To obtain the $\mathrm{Ca}^{2+} / \mathrm{Na}^{+}$permeability ratio $\left(P_{\mathrm{Ca}} / P_{\mathrm{Na}}\right)$, we measured the reversal potential of the ATP-activated current $\left(E_{\mathrm{ATP}}\right)$ in the presence of 1 or $110 \mathrm{mM}$ of external $\mathrm{Ca}^{2+}$ by stepping the holding potential $\left(V_{\mathrm{h}}\right)$ between 10 and $30 \mathrm{mV}$, using increments of $10 \mathrm{mV}$. The 1 and $110 \mathrm{mM} \mathrm{Ca}^{2+}$ solutions contained 155 or $0 \mathrm{mM} \mathrm{NaCl}$, respectively, in addition to $10 \mathrm{mM}$ HEPES with $\mathrm{pH}$ adjusted to 7.4 with $\mathrm{NaOH}$ or $\mathrm{Ca}(\mathrm{OH})_{2}$, respectively. The values of $P_{\mathrm{Ca}} / P_{\mathrm{Cs}}$ and $P_{\mathrm{Na}} / P_{\mathrm{Cs}}$ were calculated using the constant field equation as described by Lewis ([25]), taking the activity coefficients of $\mathrm{Na}^{+}, \mathrm{Cs}^{+}$, and $\mathrm{Ca}^{2+}$ as 0.75 , 0.75 , and 0.3 , respectively.

Measurement of $[\mathrm{Ca}]_{\text {in }}$

Dissociated AP neurons on a glass coverslip were incubated with 1-2 $\mu \mathrm{M}$ fura-2 acetoxymethyl ester (fura-2/AM), $0.1 \%$ dimethyl sulfoxide, and $1 \%$ bovine serum albumin for $45 \mathrm{~min}$ at $37{ }^{\circ} \mathrm{C}$. The coverslips were then mounted in a superfusion chamber and placed on the stage of an inverted microscope (Diaphot-TMD, Nikon, Japan). Cells were continuously superfused at a rate of $1 \mathrm{ml} / \mathrm{min}$ with HEPES-buffered saline at $24-26{ }^{\circ} \mathrm{C}$ via a polyethylene tube placed $1-2$ $\mathrm{mm}$ away from the cells.

Cells were viewed with a $40 \times$ Fluor objective lens (Nikon), and a single cell (10-12 $\mu \mathrm{m}$ diameter) was fixed in a window positioned between the photomultiplier and the microscope. The changes in fluorescence ratios at 340 and $380 \mathrm{~nm}$ excitation wavelengths were measured using a CAM-200 spectrometer (Jasco, Japan). The absolute value of $[\mathrm{Ca}]_{\text {in }}$ was calculated using the formulae as given by Grynkiewicz et al. [26]: [Ca $]_{\text {in }}=b \times \operatorname{Kd}\left(R-R_{\min }\right) /\left(R_{\max }-R\right)$. Calibration constants were determined in separate experiments with the same experimental set-up, as described previously (Sorimachi et al. [27]).
Student's paired t test was used to evaluate differences between mean values obtained from the same cells, and Student's unpaired t test was used for data obtained from different groups of cells.

\section{Reagents}

The following reagents were used: Fura-2/AM [Dojindo, Kumamoto, Japan], ACh [Horai Chem. Co., Japan], PPADS (pyridoxal-phosphate-6-azophenyl-2', 4'-disulphonic acid) [RBI, USA.], pronase [Calbiochem., USA], thermolysin, ATP, 2-methylthioATP, ATP $\gamma \mathrm{S}, \alpha, \beta$-methylene-ATP, $\beta, \gamma$-methyleneATP, ADP, nitrendipine, nicardipine, suramin [all from Sigma, Aldrich, Tokyo, Japan], $\omega$-conotoxinMVIIA, $\omega$-conotoxin-MVIIC and $\omega$-agatoxin-IVA [all from Peptide Institute, Osaka, Japan].

\section{Results}

ATP-induced current

Rapid application of ATP $(100 \mu \mathrm{M})$ to isolated AP neurons voltage clamped at a $V_{\mathrm{h}}$ of $-70 \mathrm{mV}$ induced an inward current, which desensitized slowly (Fig. 1A). The ATP-induced current $\left(I_{\mathrm{ATP}}\right)$ was recorded at various $V_{\mathrm{h}} \mathrm{s}$ between -70 and $+50 \mathrm{mV}$ (Fig. 1: $N=$ 6 ), and the relative current amplitude was plotted against $V_{\mathrm{h}}$ exhibiting a strong inward rectification. The $E_{\mathrm{ATP}}$, estimated from the intersection of the current response and the zero voltage-axis (Fig. 1B), was $22.7 \pm$ $0.9 \mathrm{mV}(N=18)$.

To investigate the ATP concentration-response relationship, care was taken to adjust the $\mathrm{pH}$ of the solutions containing higher concentrations of ATP to 7.3, since addition of ATP reduced $\mathrm{pH}$ and a small decrease in $\mathrm{pH}$ to 7.1 increased the $I_{\text {АTP }}$ to $189 \pm 8 \%$ $(N=6)$ of control ( $\mathrm{pH} 7.3)$, as previously reported for recombinant $\mathrm{P}_{2} \mathrm{X}_{2}$ receptors (King et al. [28]). The responses to different ATP concentrations were flanked by responses to the control concentration of $100 \mu \mathrm{M}$, and normalized responses were expressed relative to the average of these control responses (Fig. 1C; Ca2mM). We also examined the effects of 0.1 and $10 \mathrm{mM} \mathrm{Ca}^{2+}$ on $I_{\mathrm{ATP}}$. As summarized in Fig. 1C, an increase in the external concentration of $\mathrm{Ca}^{2+}$ shifted the concentration-response curve for ATP to the right, with the half-maximum effective concentration $\left(\mathrm{EC}_{50}\right)$ values at $0.1,2$ and $10 \mathrm{mM} \mathrm{Ca}^{2+}$ being 30, 70, and $190 \mu \mathrm{M}$, respectively. 

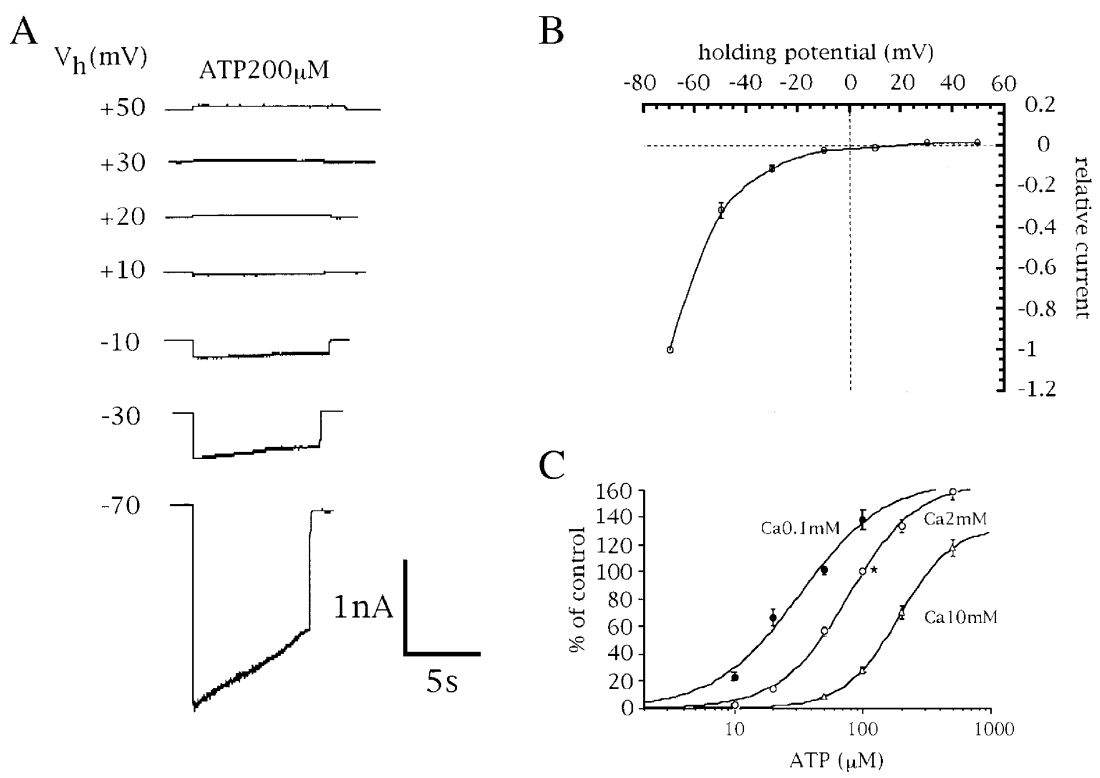

Fig. 1 Current-voltage relationship for ATP-induced currents. A) Representative currents in response to $200 \mu \mathrm{M}$ ATP recorded at $V_{\mathrm{h}}$ s between -70 and $+50 \mathrm{mV}$. B) Current-voltage relationship for the $I_{\mathrm{ATP}}$. All responses are normalized to the peak current amplitude obtained at a $V_{\mathrm{h}}$ of $-70 \mathrm{mV}$, and each point is the mean \pm S.E.M. of five neurons. C) Averaged concentration-current relationships for ATP in the presence of $0.1,2$, and $10 \mathrm{mM}$ external $\mathrm{Ca}^{2+}$. All responses were normalized to the mean of two control responses induced by $100 \mu \mathrm{M}$ ATP in saline containing $2 \mathrm{mM}$ external $\mathrm{Ca}^{2+}$ before and after the test response. Each point is the average \pm S.E.M of responses from four to six neurons.

The purinergic agonists, 2-methylthio-ATP $(50 \mu \mathrm{M})$ and ATP $\gamma \mathrm{S}(50 \mu \mathrm{M})$ induced currents that were $41 \pm$ $3 \%(N=4)$, and $41 \pm 4 \%(N=5)$, respectively, of the $I_{\mathrm{ATP}}$ in response to $100 \mu \mathrm{M}$ ATP. ADP $(0.5 \mathrm{mM}) \mathrm{did}$ not produce any response. The $I_{\mathrm{ATP}}$ in response to 50 $\mu \mathrm{M}$ ATP was inhibited by the P2 antagonists; suramin $(10 \mu \mathrm{M}$ and $20 \mu \mathrm{M})$ and PPADS $(50 \mu \mathrm{M})$, with the response being $35 \pm 2 \%(N=5), 25 \pm 2 \%(N=4)$, and $56 \pm 5 \%(N=5)$, of the control $I_{\mathrm{ATP}}$, respectively.

\section{ATP-induced $[\mathrm{Ca}]_{\text {in }}$ increase}

ATP also increased $[\mathrm{Ca}]_{\text {in }}$ in a dose-dependent manner (Fig. 2A). These responses were all recorded in the presence of $2 \mathrm{mM}$ external $\mathrm{Ca}^{2+}$, and the $[\mathrm{Ca}]_{\text {in }}$ increases by various concentrations of ATP were normalized to that induced by $100 \mu \mathrm{M}$ ATP. The normalized and averaged responses to ATP, 2-methylthio-ATP and ATP $\gamma$ S are shown in Fig. 2B. There was no ATP-induced $[\mathrm{Ca}]_{\text {in }}$ increase in the absence of external $\mathrm{Ca}^{2+}(N=6$; data not shown). Furthermore, neither ADP, $\alpha, \beta$-methylene-ATP nor $\beta, \gamma$-methyleneATP increased $[\mathrm{Ca}]_{\text {in }}$ when tested at concentrations of $200 \mu \mathrm{M}$ (data not shown). The ATP-induced [Ca $]_{\text {in }}$ increases were inhibited by suramin and PPADS (Table 1).
Effects of $\mathrm{Ca}^{2+}$ channel antagonists on ATP-induced $[\mathrm{Ca}]_{\text {in }}$ increase

Previous results, using cultured rabbit AP neurons, demonstrated the presence of a $\omega$-conotoxin-M Csensitive $\mathrm{Ca}^{2+}$ response, but that did not involve L- or $\mathrm{N}$-type $\mathrm{Ca}^{2+}$ channels (Hay et al. [29]). We also investigated the effects of various $\mathrm{Ca}^{2+}$ channel antagonists on $[\mathrm{Ca}]_{\text {in }}$ increases induced by high $\mathrm{KCl}(110 \mathrm{mM})$ and ATP $(100 \mu \mathrm{M})$. Antagonist for the L-type (nitrendipine, nicardipine), N-type ( $\omega$-conotoxin-M A), or P/Q-type ( $\omega$-conotoxin-M C) $\mathrm{Ca}^{2+}$ channels each substantially inhibited these $[\mathrm{Ca}]_{\text {in }}$ increases (Table 1 ). In contrast, the selective $\mathrm{P}$-type $\mathrm{Ca}^{2+}$ channel antagonist, $\omega$-agatoxin IVA $(1 \mu \mathrm{M})$, did not have any inhibitory effect on the $[\mathrm{Ca}]_{\text {in }}$ increases $(98 \pm 5 \%$ of control, $N=4)$.

ATP-induced current in the absence of external $\mathrm{Na}^{+}$

When external $\mathrm{Na}^{+}$was completely replaced by $\mathrm{NMDG}^{+}$, and in the absence of external $\mathrm{Ca}^{2+}\left(0 \mathrm{Ca}^{2+}\right.$ plus $0.5 \mathrm{mM}$ EGTA), the $I_{\mathrm{ATP}}$ was markedly reduced to $8 \pm 1 \%$ of the control $I_{\mathrm{ATP}}$ recorded in the presence of external $\mathrm{Ca}^{2+}$ and $150 \mathrm{mM} \mathrm{Na}^{+}(N=9$, Fig. 3A). This current was further reduced to $4 \pm 1 \%$ $(N=3)$ in the presence of $20 \mu \mathrm{M}$ suramin. The small 


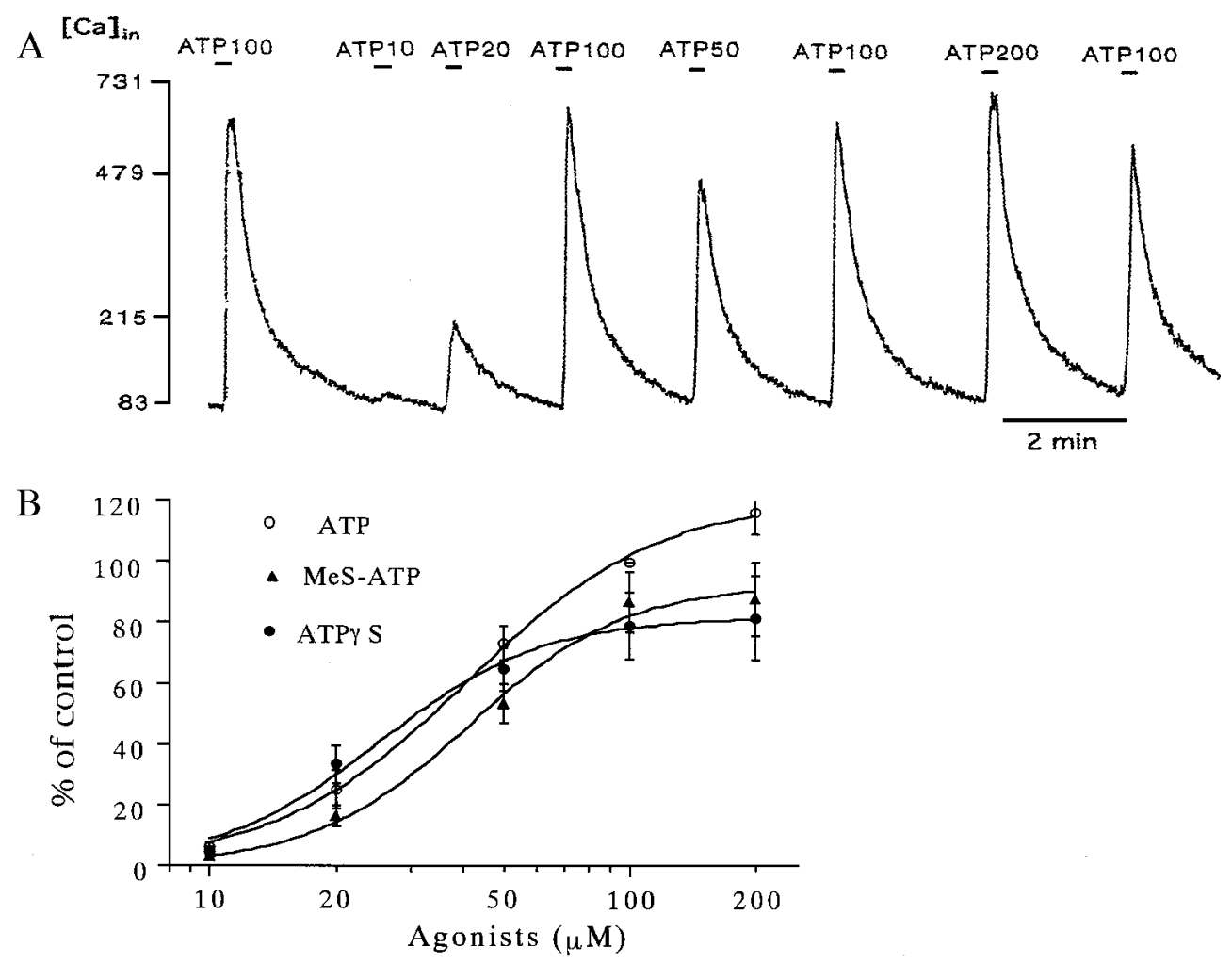

Fig. 2 Concentration-response relationships for the $[\mathrm{Ca}]_{\text {in }}$ increases in response to ATP and ATP analogues. A) Representative $[\mathrm{Ca}]_{\text {in }}$ increases induced by various concentrations of ATP in the presence of $2 \mathrm{mM}$ external $\mathrm{Ca}^{2+}$. B) Averaged concentration-response relationships for ATP and ATP analogues. All responses were normalized to the mean of two control responses induced by $100 \mu \mathrm{M}$ ATP before and after the test response. Each point is the mean \pm S.E.M. of data from five to nine neurons. MeS-ATP: 2-methylthioATP.

Table 1 Effects of P2 receptor antagonists and $\mathrm{Ca}^{2+}$ channel blockers on the $[\mathrm{Ca}]_{\text {in }}$ increases induced by ATP and high $\mathrm{K}^{+}$-saline

\begin{tabular}{|c|c|c|}
\hline Stimulus & Blockers & Percent of control \\
\hline \multirow[t]{7}{*}{ ATP100 M } & Suramin $10 \mathrm{M}$ & $55 \pm 7(N=5)$ \\
\hline & $20 \mathrm{M}$ & $30 \pm 5(N=6)$ \\
\hline & $50 \mathrm{M}$ & $13 \pm 3(N=5)$ \\
\hline & PPADS $10 \mathrm{M}$ & $96 \pm 6(N=3)$ \\
\hline & $20 \mathrm{M}$ & $70 \pm 8(N=9)$ \\
\hline & $50 \mathrm{M}$ & $25 \pm 5(N=6)$ \\
\hline & $100 \mathrm{M}$ & $11 \pm 5(N=4)$ \\
\hline \multirow[t]{4}{*}{$110 \mathrm{mMKCl}$} & Nitrendipine $2 \mathrm{M}$ & $44 \pm 4(N=16)$ \\
\hline & -CT.M C 2 M & $61 \pm 4(N=16)$ \\
\hline & -CT.M A 2 M & $62 \pm 6(N=16)$ \\
\hline & -CT.M A 2 M + -CT.M C 2 M & $58 \pm 5(N=10)$ \\
\hline \multirow[t]{4}{*}{ ATP100 M } & Nitrendipine $2 \mathrm{M}$ & $56 \pm 4(N=21)$ \\
\hline & Nicardipine $2 \mathrm{M}$ & $47 \pm 9(N=10)$ \\
\hline & $\mathrm{Cd}^{2+} 50 \mathrm{M}$ & $27 \pm 3(N=14)$ \\
\hline & -CT.M A 2 M + -CT.M C 2 M & $77 \pm 9(N=4)$ \\
\hline
\end{tabular}

The mean $[\mathrm{Ca}]_{\text {in }}$ increase induced by the first and third applications of ATP $(100 \mu \mathrm{M})$ or $110 \mathrm{mM} \mathrm{KCl}$ were averaged and referred to as $100 \%$, and the response in the presence of the $\mathrm{P} 2$ antagonist or $\mathrm{Ca}^{2+}$ channel blocker was expressed as a percentage of this control value. The cell was pre-treated for $30 \mathrm{~s}$ with the indicated agent before the second stimulation with $100 \mu \mathrm{M} \mathrm{ATP}$ or $110 \mathrm{mM} \mathrm{KCl}$. Number of experiments is shown in parentheses. $\omega$-CT $\omega$-conotoxin. 
suramin-sensitive, $\mathrm{Na}^{+}$-independent current supports the previous suggestion that the P2XR channel is permeable to glucosamine (Nakazawa [30]). To confirm this, ATP did not induce a current at all when sucrose $(0.25 \mathrm{M})$ was substituted for $\mathrm{NaCl}$ (again in the absence of external $\mathrm{Ca}^{2+}, N=5$ ). Addition of $\mathrm{Ca}^{2+}$ to the $\mathrm{NMDG}^{+}$- substituted saline further increased $I_{\mathrm{ATP}}$. The currents induced by $500 \mu \mathrm{M}$ ATP in the presence of 2 and $10 \mathrm{mM} \mathrm{Ca}^{2+}$, but in the absence of external $\mathrm{Na}^{+}$(replaced by $\mathrm{NMDG}^{+}$) were $18 \pm 2 \%(N=11)$ and $29 \pm 2 \%(N=14$, Fig. $3 \mathrm{~B})$ of the control $I_{\mathrm{ATP}}$, respectively. Similarly, the currents induced by $500 \mu \mathrm{M}$ ATP in the presence of 2 and $10 \mathrm{mM} \mathrm{Ca}^{2+}$ added to the sucrose-substituted saline were $6 \pm 1 \%(N=6)$, and $13 \pm 2 \%(N=16$; Fig. $3 \mathrm{C})$ of the control $I_{\mathrm{ATP}}$, respectively.

We also measured the $E_{\mathrm{ATP}}$ of $I_{\mathrm{ATP}}$ in the presence of $1 \mathrm{mM}$ external $\mathrm{Ca}^{2+}$ and $150 \mathrm{mM} \mathrm{NaCl}$ or $110 \mathrm{mM}$ external $\mathrm{Ca}^{2+}$ and $0 \mathrm{mM} \mathrm{NaCl}$. The $E_{\text {ATP }}$ at $110 \mathrm{mM}$
A

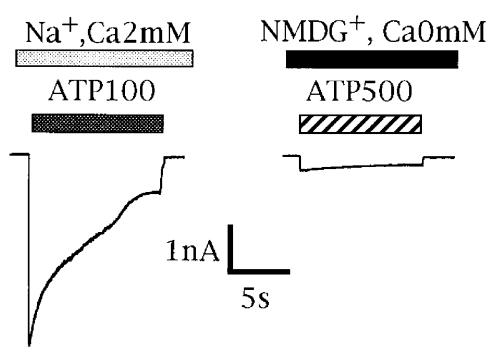

B

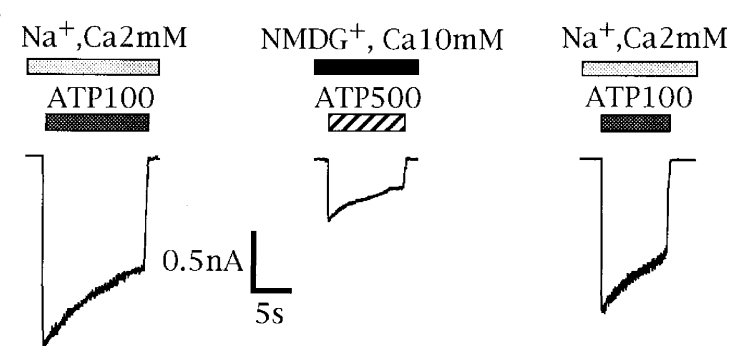

$\mathrm{C}$

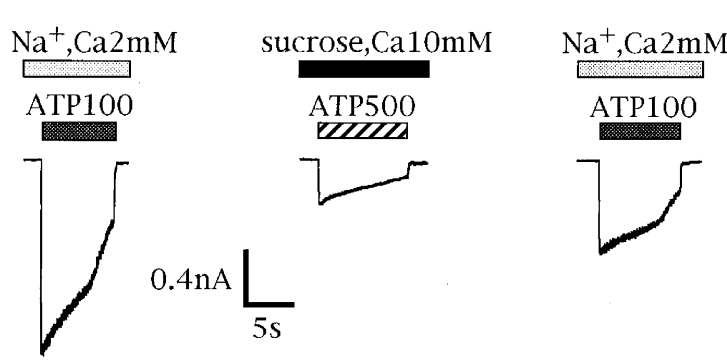

Fig. 3 ATP-induced current in $\mathrm{Na}^{+}$- and $\mathrm{NaCl}$-free saline containing 0 and $10 \mathrm{mM} \mathrm{Ca}^{2+}$. A) A representative $I_{\mathrm{ATP}}$ recorded in $\mathrm{Na}^{+}$-free $\left(\mathrm{Na}^{+}\right.$replaced by $\left.\mathrm{NMDG}^{+}\right)$and $\mathrm{Ca}^{2+}$-free saline (containing $0.5 \mathrm{mM}$ EGTA) at a $V_{\mathrm{h}}$ of $-70 \mathrm{mV}$. B) A representative $I_{\mathrm{ATP}}$ in $\mathrm{Na}^{+}$-free $\left(\mathrm{NMDG}^{+}\right)$saline containing 10 $\left.\mathrm{mM} \mathrm{Ca}^{2+} . \mathbf{C}\right)$ A representative $I_{\mathrm{ATP}}$ in $\mathrm{NaCl}$-free $(\mathrm{NaCl}$ replaced by sucrose) saline containing $10 \mathrm{mM} \mathrm{Ca}^{2+}$.
$\mathrm{Ca}^{2+}$ was $21.1 \pm 1.0 \mathrm{mV}(N=18)$, from which we calculated a $P_{\mathrm{Ca}} / P_{\mathrm{Cs}}$ of 6.3 . The $E_{\mathrm{ATP}}$ at $1 \mathrm{mM} \mathrm{Ca} \mathrm{Ca}^{2+}$ was $20.2 \pm 1.0 \mathrm{mV}(N=13)$, from which we calculated a $P_{\mathrm{Na}} / P_{\mathrm{Cs}}$ ratio of 2.1. From these, we obtained a $P_{\mathrm{Ca}} /$ $P_{\mathrm{Na}}$ ratio of 3.0 , confirming the substantial $\mathrm{Ca}^{2+}$ permeability of P2XRs.

Negative interaction between P2XR and nAChR channels

Requirement of actual current flow through receptor channels for cross-inhibition.

It has previously been reported that there is mutual occlusion between P2XR and nAChR in some neurons (Nakazawa et al. [18]; Nakazawa [30]; Searl et al. [19]; Zhou and Galligan [20]; Barajas-Lopez et al. [21]; Khakh et al. [22, 23]; Boue-Grabot et al. [24]). To examine whether there were negative interactions between the ACh-activated current $\left(I_{\mathrm{ACh}}\right)$ and $I_{\mathrm{ATP}}$, one receptor agonist was added in the presence of the other. As shown in Fig. 4A, the $I_{\mathrm{ACh}}(100 \mu \mathrm{M})$ was markedly reduced when activated in the presence of ATP $(50 \mu \mathrm{M})$. We next examined $I_{\mathrm{ACh}}(100 \mu \mathrm{M})$ in the presence of various concentrations of ATP. With 2, 10, 20 , and $100 \mu \mathrm{M}$ ATP, $I_{\mathrm{ACh}}$ was reduced to $95 \pm 1 \%$ $(N=20), 84 \pm 2 \%(N=24), 60 \pm 4 \%(N=15)$, and $46 \pm$ $6 \%(N=7)$, respectively, of control $(P<0.01$ except at $2 \mu \mathrm{M}$ ATP). Thus, the $I_{\mathrm{ACh}}$ inhibition became stronger as the concentration of ATP was increased and with a higher agonist-receptor occupancy. In fact, when $I_{\text {ATP }}$ at $100 \mu \mathrm{M}$ ATP was markedly inhibited in the presence of $200 \mu \mathrm{M}$ PPADS $(8 \pm 2 \%$ of control, $N=6), I_{\mathrm{ACh}}$ was not occluded ( $97 \pm 1 \%$ of control; $N=6$ ). When the peak amplitude of $I_{\text {ATP }}$, evoked by various concentrations of ATP, was plotted against the ratio of $I_{\mathrm{ACh}}$ in the presence and absence of ATP, there was an inverse correlation between the amplitudes of these responses (Fig. 4B). Conversely, when ATP $(50 \mu \mathrm{M})$ was applied in the presence of ACh $(100 \mu \mathrm{M}), I_{\mathrm{ATP}}$ was also occluded (Fig. 4C). Again, when $I_{\mathrm{ACh}}$ at 200 $\mu \mathrm{M}$ ACh was nullified in the presence of $1 \mathrm{mM}$ hexamethonium, a nAChR antagonist $(0.2 \pm 0.2 \%$ of control, $N=6), I_{\mathrm{ATP}}$ was $96 \pm 2 \%(N=6)$ of control. $I_{\mathrm{ACh}}$ at $10,20,50$, and $200 \mu \mathrm{M}$ ACh were $6 \pm 2 \%$ $(N=5), 20 \pm 4 \%(N=5), 61 \pm 8 \%(N=6)$, and $139 \pm$ $8 \%(N=6)$ of $I_{\mathrm{ACh}}$ at $100 \mu \mathrm{M}$. There was also an inverse correlation between the peak amplitude of $I_{\mathrm{ACh}}$, evoked by various concentrations of $\mathrm{ACh}$, and the ratio of $I_{\mathrm{ATP}}$ in the presence and absence of ACh (Fig. 4D). However, the inhibition of $I_{\mathrm{ATP}}$ by nAChR activation was weaker than that of $I_{\mathrm{ACh}}$ by P2XR activation. As the $I_{\mathrm{ACh}}$ desensitized faster than the $I_{\mathrm{ATP}}$, the weaker inhibition of $I_{\mathrm{ATP}}$ by ACh could be 
A

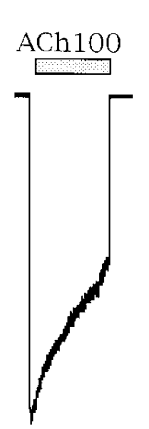

ATP50

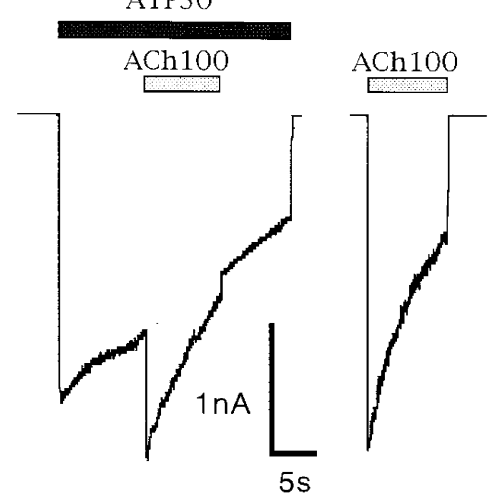

$\mathrm{B}$

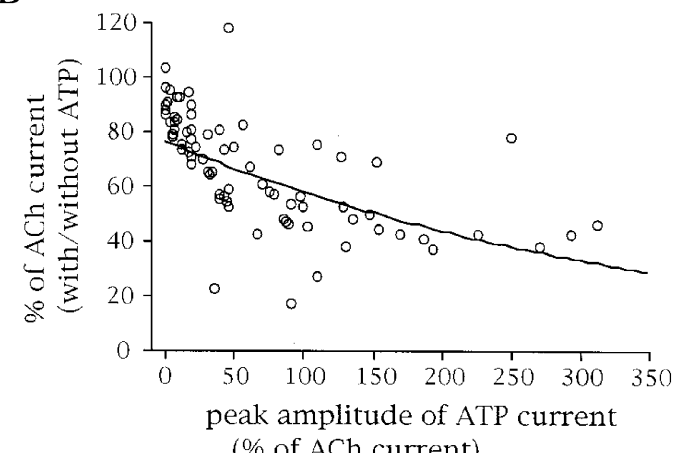

$\mathrm{C}$

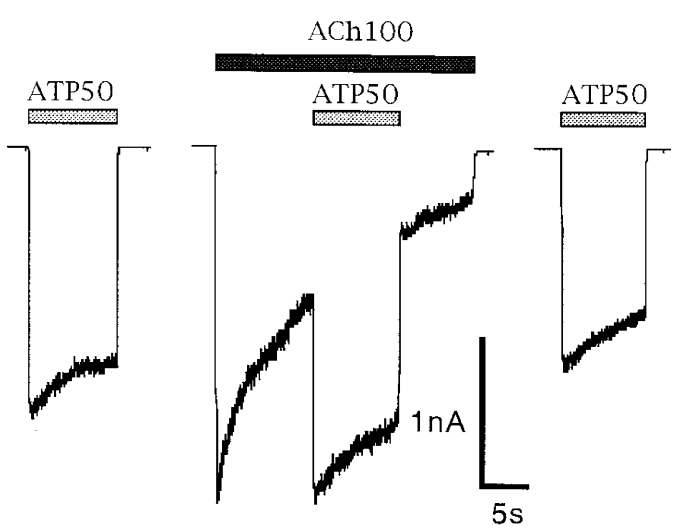

$\mathrm{D}$

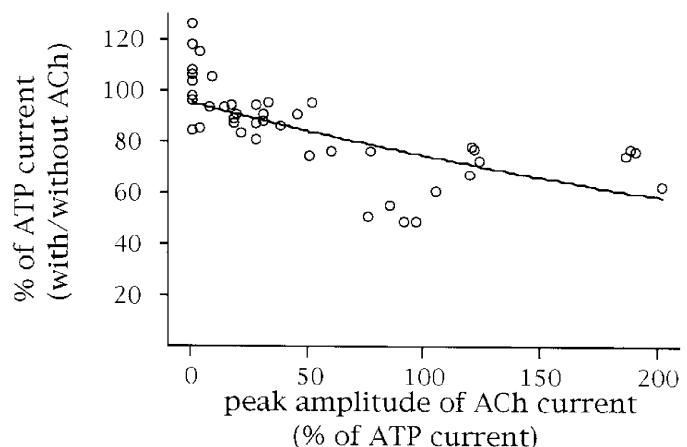

Fig. 4 Inhibition of $I_{\mathrm{ACh}}$ and $I_{\mathrm{ATP}}$, respectively, in the presence of ATP and ACh. A) Sample currents in response to ACh (100 $\left.\mu \mathrm{M}\right)$ in the presence of ATP $(50 \mu \mathrm{M})$. The responses to ACh applied in the presence of ATP were reduced. The extent of occlusion was normalized to the control ACh responses recorded before and after ATP application. This sequence was routinely repeated twice or three times, and the averaged amount of occlusion was plotted in B. B) Relative amplitude of the ACh current amplitude in the presence of ATP (ordinate) plotted against the peak amplitude of $I_{\mathrm{ATP}}$ obtained in the same neuron (abscissae). Note the negative correlation between these two variables. The line was drawn using KaleidaGraph (Synergy Software). $V_{\mathrm{h}}:-70 \mathrm{mV}$. C) The $I_{\mathrm{ATP}}$ was recorded in the presence of $100 \mu \mathrm{M}$ ACh and this response was flanked by control ATP alone responses. This sequence was routinely obtained twice or three times in the same cell, and the averaged amount of occlusion was plotted in D. D) The ratio of the ATP current amplitude in the presence and absence of ACh (ordinate) is negatively correlated with the peak amplitude of $I_{\mathrm{ACh}}($ abscissae). $V_{\mathrm{h}}:-70 \mathrm{mV}$.

due to the reduced amplitude of the $I_{\mathrm{ACh}}$ at the time of ATP application.

To examine this possibility, $I_{\mathrm{ATP}}$ was measured in the presence of both ACh and d-tubocurarine (dTc, 10 $\mu \mathrm{M})$ or serotonin $(5 \mathrm{HT}, 50 \mu \mathrm{M})$, two experimental conditions which change the time course of the $I_{\mathrm{ACh}}$ response. The former agent, $\mathrm{dTc}$, has been shown to be both an open channel blocker and a competitive antagonist of nAChR (Manalis [31]), and, as expected, a low concentration $(10 \mu \mathrm{M})$ slightly reduced the peak amplitude of $I_{\mathrm{ACh}}(79 \pm 4 \%$ of control, $N=11)$ and caused the $I_{\mathrm{ACh}}$ to be terminated within $0.5 \mathrm{~s}$ (Fig. $5 \mathrm{~A}$, insert). Once the $I_{\mathrm{ACh}}$ response had returned to baseline (in the presence of $\mathrm{ACh}$ and $10 \mu \mathrm{M} \mathrm{dTc}$ ) and ATP was applied, there was no inhibition of $I_{\mathrm{ATP}}$ (95 $\pm 1 \%$ of control, $N=5$; Fig. $5 \mathrm{~A}$ ). The $I_{\mathrm{ATP}}$ in the presence of ACh alone was $77 \pm 4 \%$ of control $(N=5$, $P<0.01$; Fig. 5A). When we measured the current $\left(I_{\mathrm{ACh}+\mathrm{ATP}+\mathrm{dTc}}\right)$ induced by a combination of $\mathrm{ACh}$,
ATP and dTc, the peak amplitude of $I_{\mathrm{ACh}+\mathrm{ATP}+\mathrm{dTc}}$ was occluded under these conditions, being $74 \pm 2 \%$ $(N=10)$ of the predicted sum of $I_{\mathrm{ATP}}$ and $I_{\mathrm{ACh}+\mathrm{dTc}}$ (Fig. 5B). The level of $I_{\mathrm{ACh}+\mathrm{ATP}+\mathrm{dTc}}$ at $0.5 \mathrm{~s}$ following ligand application, which corresponds to a time when the nAChR channels are completely blocked (Fig. 5A, insert), was $96 \pm 3 \%(N=8)$ of the control $I_{\mathrm{ATP}}$, measured immediately before and after (Fig. 5C). These results suggest that the inhibition of $I_{\text {ATP }}$ by $I_{\mathrm{ACh}}$ disappears immediately after the $I_{\mathrm{ACh}}$ is abolished, although ACh is still present and bound to the nAChRs. 5HT has been shown to also accelerate the decay of $I_{\mathrm{ACh}}$ (Grassi et al. [32]; Garcia-Colunga and Miledi [33]; Sorimachi and Wakamori [34]), but not to the same extent as dTc. $5 \mathrm{HT}$ at $50 \mu \mathrm{M}$ decreased the peak amplitude of $I_{\mathrm{ACh}}$ slightly, to $88 \pm 4 \%(N=6)$ of control, and reduced the time constant (tau) of $I_{\mathrm{ACh}}$ decay from $2.02 \pm 0.18$ to $1.06 \pm 0.19 \mathrm{~s}(N=6)$. As shown in Fig. $5 \mathrm{D}$, the extent of inhibition of $I_{\mathrm{ATP}}$ by 
A

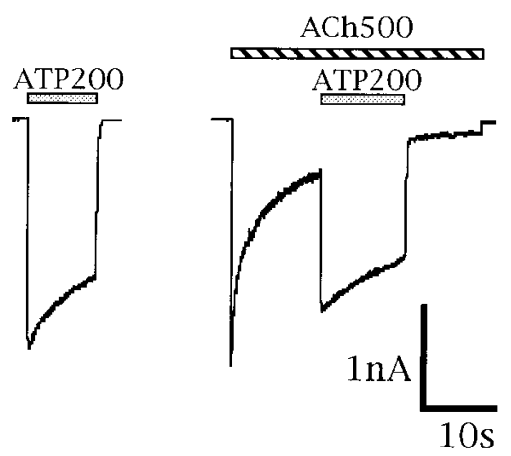

B

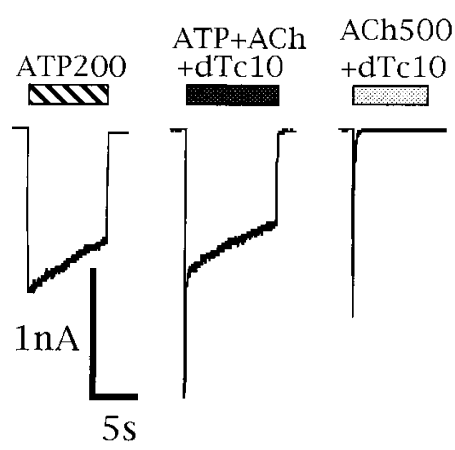

$\mathrm{D}$

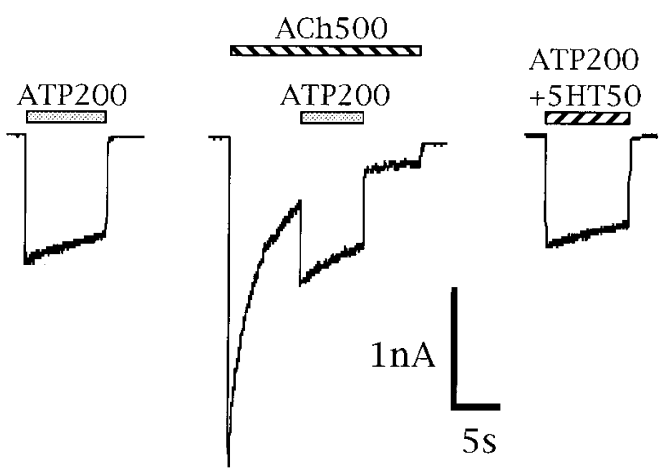

ACh $500+$ dTc 10

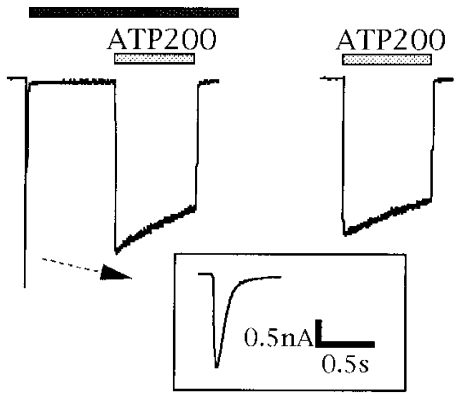

$\mathrm{C}$

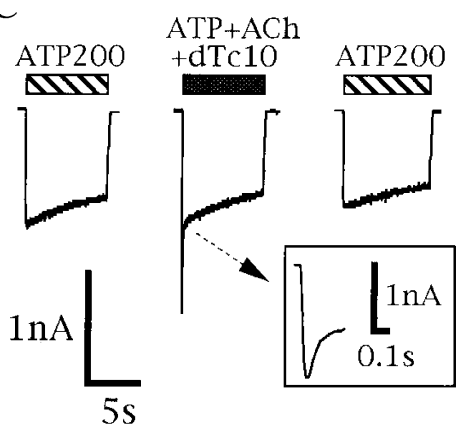

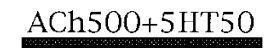

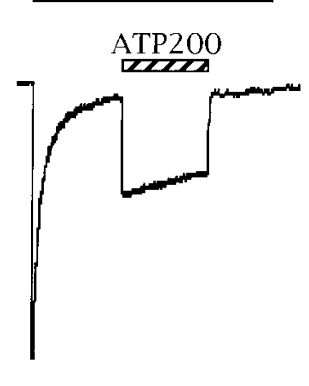

Fig. 5 Loss of the inhibition of $I_{\mathrm{ATP}}$ by ACh in the presence of dTc and 5HT. A) Representative $I_{\mathrm{ATP}}$ in control conditions (applied alone), in the presence of ACh and in the presence of ACh and dTc. This sequence was routinely repeated twice, and the averaged response was obtained. Note the very transient nature of $I_{\mathrm{ACh}}$ in the presence of dTc, with the current returning to baseline levels within $0.5 \mathrm{~s}$ (insert). Note also the lack of occlusion under these conditions. $V_{\mathrm{h}}:-70 \mathrm{mV}$. B) Effect of dTc on $I_{\mathrm{ACh}}+\mathrm{ATP}$. The sequence of applications was repeated multiple times in each neuron. The peak amplitude of $I_{\mathrm{ACh}+\mathrm{ATP}+\mathrm{dTc}}$ was smaller than the predicted sum of $I_{\mathrm{ATP}}$ and $I_{\mathrm{ACh}+\mathrm{dTc}}$. C) Rapid recovery of $I_{\mathrm{ATP}}$ from inhibition by ACh in the presence of dTc. The amplitude of $I_{\mathrm{ACh}+\mathrm{ATP}+\mathrm{dTc}} 0.5 \mathrm{~s}$ following application was equal to the mean of two control $I_{\mathrm{ATP}}$ at an equivalent time. Inset shows the rapid decline of $I_{\mathrm{ACh}+\mathrm{ATP}+\mathrm{dTc}}$ on an expanded time scale. D) Representative $I_{\mathrm{ATP}}$ in control conditions, in the presence of ACh, and in the presence of both ACh and 5HT. In this example, the tau of $I_{\mathrm{ACh}}$ in response to the first application was $2.7 \mathrm{~s}$, while the tau of $I_{\mathrm{ACh}+5 \mathrm{HT}} \mathrm{was} 0.9 \mathrm{~s}$, showing the acceleration of the $I_{\mathrm{ACh}}$ decay by $5 \mathrm{HT}$. Note the reduced occlusion under these conditions. $V_{\mathrm{h}}:-70 \mathrm{mV}$.

ACh was smaller (to $92 \pm 2 \%$ of control, $N=6$ ) in the presence of $\mathrm{ACh}$ and $5 \mathrm{HT}$ compared to that in the presence of ACh alone (to $73 \pm 3 \%$ of control, $N=6$; $P<0.01)$.

Next, we measured the current induced by the concomitant applications of ACh and ATP $\left(I_{\mathrm{ACh}+\mathrm{ATP}}\right)$ at a $V_{\mathrm{h}}$ of $-70 \mathrm{mV}$. As shown in Fig. $6 \mathrm{~A}, I_{\mathrm{ACh}+\mathrm{ATP}}$ was $75 \pm 1 \%(N=44 ; P<0.01)$ of the predicted sum of $I_{\mathrm{ACh}}$ and $I_{\mathrm{ATP}}$. The decay phase of $I_{\mathrm{ACh}}, I_{\mathrm{ATP}}$ and
$I_{\mathrm{ACh}+\mathrm{ATP}}$ were fit to a single exponential function, giving tau of $3.0 \pm 0.2,7.5 \pm 0.6$ and $3.7 \pm 0.2 \mathrm{~s}$, respectively. When the decay of $I_{\mathrm{ACh}}$ was accelerated by the presence of $100 \mu \mathrm{M} 5 \mathrm{HT}$, the tau of $I_{\mathrm{ACh}}, I_{\mathrm{ATP}}$, and $I_{\mathrm{ACh}+\mathrm{ATP}}$ were $0.8 \pm 0.3 \mathrm{~s}(N=7), 7.4 \pm 1.4 \mathrm{~s}(N=$ 7) and $2.6 \pm 0.8 \mathrm{~s}(N=7)$, respectively (the amplitude of $I_{\mathrm{ACh}}+\mathrm{ATP}$ under these conditions was $76 \pm 2 \%$ of the predicted sum of $I_{\mathrm{ACh}}$ and $\left.I_{\mathrm{ATP}}\right)$. Thus, $I_{\mathrm{ACh}+\mathrm{ATP}}$ desensitization occurs with kinetics that cannot be 

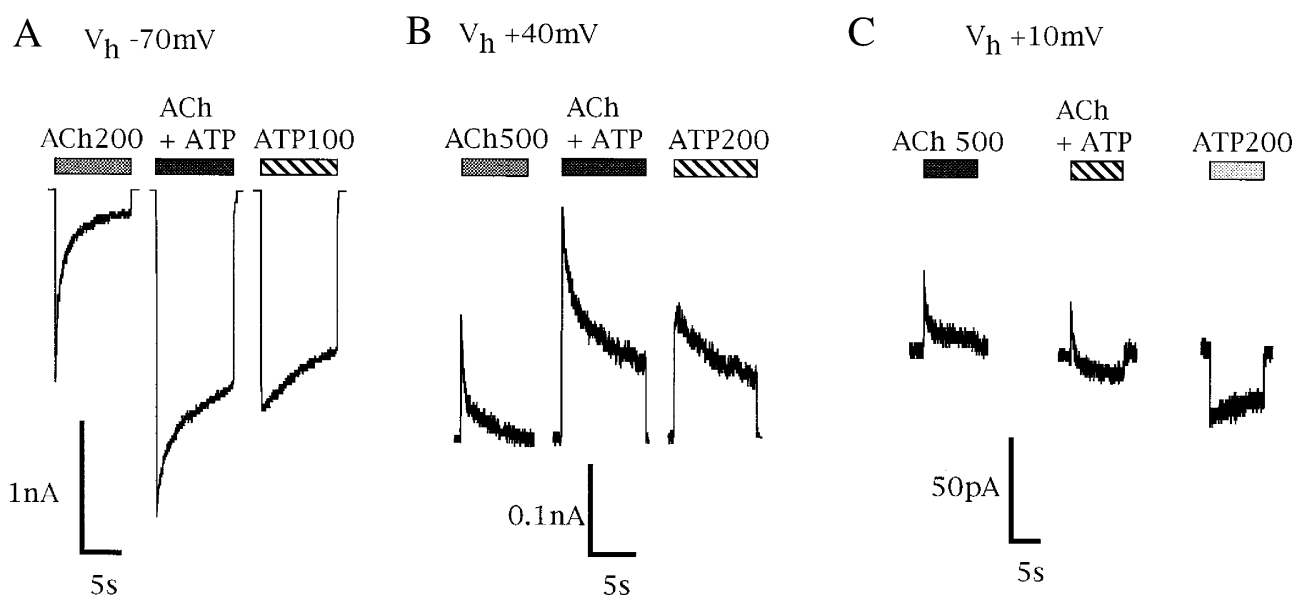

Fig. 6 Voltage dependence of $I_{\mathrm{ACh}}$ and of $I_{\mathrm{ATP}}$ occlusion. A) At a $V_{\mathrm{h}}$ of $-70 \mathrm{mV}$, co-application of ACh $(200 \mu \mathrm{M})$ and ATP $(100 \mu \mathrm{M})$ induced an inward current that was smaller in amplitude than the predicted sum of the individual $I_{\mathrm{ACh}}$ and $I_{\mathrm{ATP}}$. B) At a $V_{\mathrm{h}}$ of $+40 \mathrm{mV}$, the amplitude of the outward current induced by the co-application of ACh $(500 \mu \mathrm{M})$ and ATP $(200 \mu \mathrm{M})$ was equal to the predicted sum of the individual $I_{\mathrm{ACh}}$ and $I_{\mathrm{ATP}}$. C) Co-application of ATP and ACh does not markedly change $E_{\mathrm{ACh}}$ or $E_{\mathrm{ATP}}$. Representative currents induced by ACh, ATP, and by co-application of ACh and ATP at a $V_{\mathrm{h}}$ of $+10 \mathrm{mV}$. Note that $I_{\mathrm{ACh}}+\mathrm{ATP}$ is composed of early outward and delayed inward current, corresponding to the ACh component and the ATP component, respectively.

explained by the desensitization kinetics of $I_{\mathrm{ACh}}$ or $I_{\mathrm{ATP}}$ alone, suggesting that $I_{\mathrm{ACh}+\mathrm{ATP}}$ is mediated via both receptors.

When $\mathrm{Ca}^{2+}$ was omitted from extracellular solution, the negative interaction between the two receptor channels was still obtained; with $I_{\mathrm{ACh}}+$ ATP being $77 \pm$ $1 \%(N=5 ; P<0.01)$ of the predicted sum of $I_{\mathrm{ACh}}$ and $I_{\mathrm{ATP}}$. Hence negative interaction is not mediated by a $\mathrm{Ca}^{2+}$ influx-dependent mechanism, although both nAChR and P2XR are $\mathrm{Ca}^{2+}$-permeable cation channels (Fieber and Adams [35]; Rogers and Dani [36]). This result, however, does not necessarily rule out the possible involvement of $[\mathrm{Ca}]_{\text {in }}$ in negative interaction.

Occlusion was not only observed at a $V_{\mathrm{h}}$ of -70 $\mathrm{mV} ; I_{\mathrm{ACh}}+\mathrm{ATP}$ at $V_{\mathrm{h}} \mathrm{s}$ of -20 , and $-10 \mathrm{mV}$ were $80 \pm$ $2 \%(N=12 ; P<0.01)$, and $76 \pm 2 \%(N=8 ; P<0.01)$, respectively, of the predicted sum of $I_{\mathrm{ACh}}$ and $I_{\mathrm{ATP}}$. In sharp contrast, such occlusion was not observed at a positive potential; the outward current caused by coapplication of ACh and ATP at a $V_{\mathrm{h}}$ of $+40 \mathrm{mV}$ was $100 \pm 1 \%(N=10)$ of the predicted sum of individual current (Fig. 6B).

We next investigated the possibility that the combined addition of ACh and ATP alters the driving force for $\mathrm{Na}^{+}$, by attempting to measure $E_{\mathrm{ACh}+\mathrm{ATP}}$. In these studies, currents in response to ACh, ATP and both ligands were measured at various fixed potentials close to the reversal potential for $I_{\mathrm{ACh}}$ and $I_{\mathrm{ATP}}$. The $E_{\mathrm{ACh}}$ and $E_{\mathrm{ATP}}$ were $8.7 \pm 1.5 \mathrm{mV}(N=5)$ and $21.0 \pm$ $1.6 \mathrm{mV}(N=7)$, respectively, and $I_{\mathrm{ACh}+\text { ATP }}$ measured at a potential between these two reversal potentials (e.g.10 mV, Fig. 6C) showed a combination of both the ACh-induced outward current and the ATP-induced inward current. These results suggest that the driving force for permeant ions during combined ACh and ATP is similar to that during the application of each ligand separately.

The question arises as to whether occlusion is specific just for $\mathrm{Na}^{+}$ions or whether inward currents carried by cations other than $\mathrm{Na}^{+}$can also contribute to occlusion during co-activation of $\mathrm{nAChRs}$ and P2XRs. To address this question, we measured $I_{\mathrm{ACh}}$, $I_{\mathrm{ATP}}$, and $I_{\mathrm{ACh}+\mathrm{ATP}}$ in the presence of $\mathrm{Na}^{+}$-free $\left(\mathrm{NMDG}^{+}\right)$saline containing $10 \mathrm{mM} \mathrm{Ca}^{2+}$ (Fig. 7). $\mathrm{NMDG}^{+}$does not permeate through nAChR (Sorima-

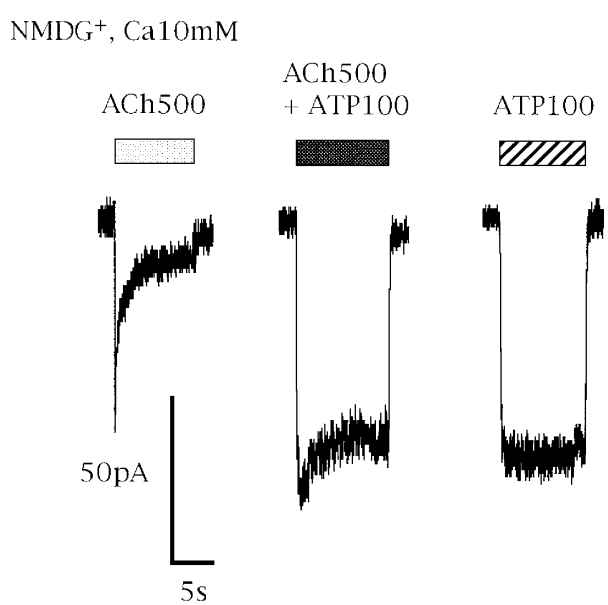

Fig. 7 Occlusion of $I_{\mathrm{ACh}}+\mathrm{ATP}$ in the presence of $\mathrm{Na}^{+}$-free saline containing $10 \mathrm{mM} \mathrm{Ca}^{2+}$. $I_{\mathrm{ACh}}, I_{\mathrm{ATP}}$ or $I_{\mathrm{ACh}+\mathrm{ATP}}$ was recorded $20 \mathrm{~s}$ after switching to $\mathrm{Na}^{+}$-free (replaced by $\mathrm{NMDG}^{+}$) saline containing $10 \mathrm{mM} \mathrm{Ca} \mathrm{Ca}^{2+}$. The sequence of applications was repeated multiple times. Following each ligand application, the external solution was changed back to normal saline containing $150 \mathrm{mM} \mathrm{Na}{ }^{+}$before the next ligand application. $V_{\mathrm{h}}:-70 \mathrm{mV}$. 

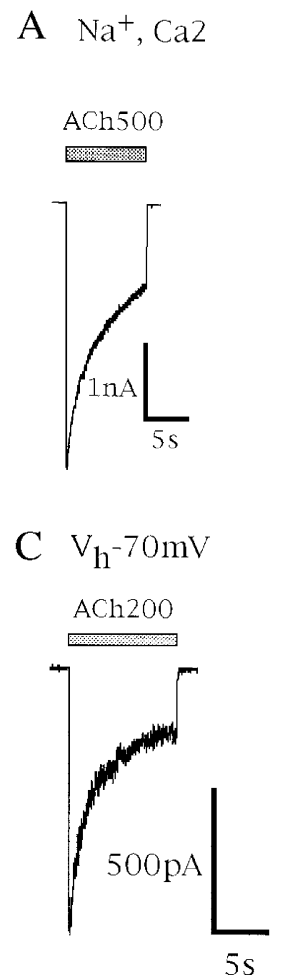

$\mathrm{B} \mathrm{NMDG}^{+}, \mathrm{CaO}$

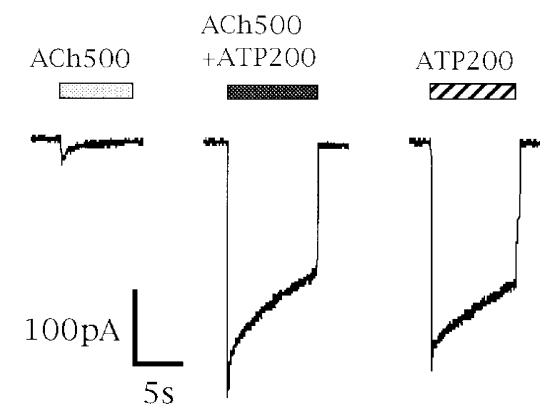

D $\mathrm{V}_{\mathrm{h}}+7 \mathrm{mV}$

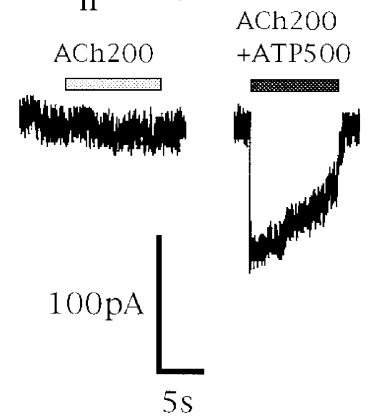

ATP500

प्W

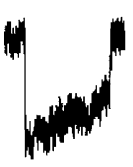

Fig. 8 Lack of inhibition in response to co-application of ACh and ATP under two experimental conditions designed to virtually eliminate $I_{\mathrm{ACh}}$. A) Control $I_{\mathrm{ACh}}$ recorded at a $V_{\mathrm{h}}$ of $-70 \mathrm{mV}$ in standard saline. B) Current responses recorded at $-70 \mathrm{mV}$ from $20 \mathrm{~s}$ after exchanging the standard saline for a $\mathrm{Na}^{+}$-free (replaced by $\mathrm{NMDG}^{+}$), $\mathrm{Ca}^{2+}$-free saline. This sequence was repeated twice or three times. Note the small amplitude of $I_{\mathrm{ACh}}$, and the lack of occlusion of $I_{\mathrm{ACh}}+\mathrm{ATP}$. C) Control $I_{\mathrm{ACh}}$ recorded at a $V_{\mathrm{h}}$ of $-70 \mathrm{mV}$ in another neuron. D) Representative traces of $I_{\mathrm{ACh}}, I_{\mathrm{ATP}}$, and $I_{\mathrm{ACh}}+\mathrm{ATP}$ recorded at a $V_{\mathrm{h}}$ of $+7 \mathrm{mV}$, which is very close to $\mathrm{E}_{\mathrm{ACh}}$. Note the lack of occlusion at this potential, when current flow through the AChR is negligible.

chi and Wakamori [16]), and hence $I_{\mathrm{ACh}}$ would be mediated by only $\mathrm{Ca}^{2+}$ influx, whereas $I_{\mathrm{ATP}}$ would be mediated via both $\mathrm{NMDG}^{+}$and $\mathrm{Ca}^{2+}$ influx (Fig. 3). Under these conditions, $I_{\mathrm{ACh}}+$ ATP was again occluded, being $70 \pm 3 \%$ of the predicted sum of $I_{\mathrm{ACh}}$ and $I_{\mathrm{ATP}}$ $(N=11 ; P<0.01$; Fig. 7$)$.

In a further attempt to distinguish whether channel activation or ion permeation was primarily responsible for occlusion of one channel by the other, we compared $I_{\mathrm{ATP}}$ with $I_{\mathrm{ACh}+\mathrm{ATP}}$ under two experimental conditions, in which a higher concentration of $\mathrm{ACh}$ should activate nAChR but produce very little current. In the absence of $\mathrm{Na}^{+}$and $\mathrm{Ca}^{2+}$ (replaced by $\mathrm{NMDG}^{+}$) application of $\mathrm{ACh}$ induces a negligible current (Sorimachi and Wakamori [16]), while ATP induces a substantial current under the same conditions (Fig. 3A). As shown in Fig. 8B, there was no occlusion in these conditions; the amplitude of $I_{\mathrm{ATP}+\mathrm{ACh}}$ was $105 \pm 1 \%$ $(N=10)$ of the predicted sum of $I_{\mathrm{ATP}}$ and $I_{\mathrm{ACh}}$. We also investigated currents in response to the ligands at a potential close to the $E_{\mathrm{ACh}}(7 \pm 2 \mathrm{mV}$ in this experiment, $N=13$ ), taking advantage of the more positive $E_{\mathrm{ATP}}(22.7 \pm 0.9 \mathrm{mV})$, so that at this potential only the $I_{\mathrm{ATP}}$ was observed. The amplitude of
$I_{\mathrm{ATP}+\mathrm{ACh}}$ was $105 \pm 3 \%(N=13)$ of that of $I_{\mathrm{ATP}}$, and $I_{\mathrm{ACh}}$ was close to zero (Fig. $8 \mathrm{D}$ ). These results are, however, in contrast to that obtained in sympathetic neurons (Nakazawa[30]), in which $I_{\mathrm{ATP}}$ in the absence of both $\mathrm{Na}^{+}$(replaced by glucosamine) and $\mathrm{Ca}^{2+}$ was inhibited in the presence of $\mathrm{ACh}$, which caused no current (Nakazawa [30]). In these experiments, we only included data in which $I_{\mathrm{ATP}}$ was large enough to be clearly resolved, greater than $50 \mathrm{pA}$ (corresponding to a control $I_{\mathrm{ATP}}$ at a $V_{\mathrm{h}}$ of $-70 \mathrm{mV}$ larger than 1.5 $\mathrm{nA})$. These results suggest that actual current flow through both nAChR and P2XR is responsible for occlusion.

\section{Discussion}

In this study, we found that ATP induced an inward current and increased $[\mathrm{Ca}]_{\text {in }}$ in isolated rat AP neurons. The ATP-induced current and $[\mathrm{Ca}]_{\text {in }}$ increase were mimicked by ATP $\gamma \mathrm{S}$ and 2-methylthio-ATP, but not by $\alpha, \beta$-methylene-ATP, $\beta, \gamma$-methylene-ATP nor ADP, and was inhibited by suramin and PPADS, suggesting that it was mediated by P2XRs. These 
results are in good agreement with previous histochemical findings, which demonstrated the presence of $\mathrm{P} 2 \mathrm{X}_{2}, \mathrm{P} 2 \mathrm{X}_{4}$, and $\mathrm{P} 2 \mathrm{X}_{6}$ receptor mRNAs (Collo et al. [37]), and of $\mathrm{P}_{2} \mathrm{X}_{2}$ receptor immunoreactivity in $\mathrm{AP}$ neurons (Kanjhan et al. [38]; Atkinson et al. [39]).

The $I_{\mathrm{ATP}}$ showed strong inward rectification and the $E_{\text {ATP }}$ was $22.7 \pm 0.9 \mathrm{mV}$ (Fig. 1B). The amplitude of $I_{\text {ATP }}$ varied inversely with the extracellular $\mathrm{Ca}^{2+}$ concentrations (Fig. 1C). The inhibitory effect of increasing extracellular $\mathrm{Ca}^{2+}$ has also been reported in rat sensory neurons (Krishtal et al. [40]), PC-12 cells (Nakazawa et al. [18]), ventromedial hypothalamic neurons (Sorimachi et al. [41]), and in cells expressing recombinant $\mathrm{P}_{2} \mathrm{X}_{2}$ receptors (Evans et al. [42]; Virginio et al. [43]), where an allosteric alteration of the ATP binding sites has been suggested to be the underlying mechanism.

The $I_{\text {ATP }}$ was markedly reduced, but still persisted when $\mathrm{NMDG}^{+}$was substituted for external $\mathrm{Na}^{+}$even in the absence of $\mathrm{Ca}^{2+}$ (Fig. 3A). Since ATP did not induce a current when sucrose was substituted for external $\mathrm{NaCl}$, our result suggests that $\mathrm{NMDG}^{+}$could permeate through P2XR. A substantial $I_{\mathrm{ATP}}$ has been similarly reported in PC-12 cells and sympathetic neurons when glucosamine was substituted for $\mathrm{Na}^{+}$ (Nakazawa et al. [18]; Nakazawa [30]). The addition of $\mathrm{Ca}^{2+}$ to NMDG-Cl- and sucrose-substituted saline increased the $I_{\mathrm{ATP}}$ (Fig. $3 \mathrm{~B}$ and $\mathrm{C}$, respectively), indicating that $\mathrm{Ca}^{2+}$ also permeates through P2XR channel. We quantified the relatively high $\mathrm{Ca}^{2+}$ permeability, obtaining a $P_{\mathrm{Ca}} / P_{\mathrm{Na}}$ ratio of 3.0. A relatively high permeability of P2XR to $\mathrm{Ca}^{2+}$ has been reported in previous studies (Nakazawa et al. [18]; Sorimachi et al. [41]; Evans et al. [42]; Virginio et al. [43]). Although direct influx of extracellular $\mathrm{Ca}^{2+}$ through P2XR channel may thus contribute to the ATPinduced $[\mathrm{Ca}]_{\text {in }}$ increase, membrane depolarization and the secondary activation of voltage-dependent $\mathrm{Ca}^{2+}$ channels could also make a significant contribution to the $[\mathrm{Ca}]_{\text {in }}$ increase. In fact, the high $\mathrm{K}^{+}$- and ATP-induced $[\mathrm{Ca}]_{\text {in }}$ increases were substantially inhibited by a range of $\mathrm{Ca}^{2+}$ channel antagonists, including those which block $\mathrm{L}$ - and $\mathrm{N}$-type $\mathrm{Ca}^{2+}$ channels (Table 1). This is in contrast to a previous study, which reported an absence of the L- and N-type $\mathrm{Ca}^{2+}$ channels in rabbit AP neurons (Hay et al. [12]). The discrepancies between their results and ours could be, at least in part, accounted for by the use of different AP preparations (cultured rabbit neurons $v s$. acutely dissociated rat neurons).

The present results, in combination with our previous demonstration of $\mathrm{nAChR}$ on AP neurons (Sorimachi and Wakamori [16]), suggest that both
ATP and ACh may act as excitatory neurotransmitters in AP neurons, although their release from presynaptic nerve terminals has not yet been reported. We also report a negative functional interaction between P2XRs and nAChRs in AP neurons, as has been observed in a variety of peripheral neurons and in recombinant expression systems (Nakazawa et al. [18]; Nakazawa [30]; Zhou and Galligan [20]; BarajasLopez et al. [21]; Searl et al. [19]; Khakh et al. [22, 23]; Boue-Grabot et al. [24]). This is the first report, that we are aware of, of such interactions occurring in central neurons. When ACh was applied in the presence of ATP, there was a positive correlation between the peak amplitude of inward $I_{\mathrm{ATP}}$ and the amount of occlusion of inward $I_{\mathrm{ACh}}$ (Fig. $4 \mathrm{~A}$ and B). The converse was also true when ATP was applied in the presence of ACh (Fig. 4C and D). Non-additivity of the $I_{\mathrm{ACh}}+\mathrm{ATP}$ was observed even when the inward current was carried by $\mathrm{NMDG}^{+}$and/or $\mathrm{Ca}^{2+}$ (Fig. 7). Co-application of two agonists did not seem to change the driving force for $\mathrm{Na}^{+}$, because at a $V_{\mathrm{h}}$ between $E_{\mathrm{ACh}}$ and $E_{\mathrm{ATP}}$ an outward current due to the activation of $\mathrm{nAChR}$, followed by an inward current due to the activation of P2XR, was observed (Fig. 6C). Occlusion was also observed at a $V_{\mathrm{h}}$ of $-10 \mathrm{mV}$, which is closer to $E_{\mathrm{ACh}}$ or $E_{\mathrm{ATP}}$. Furthermore, the removal of external $\mathrm{Ca}^{2+}$ did not alter the occlusion, and thus a $\mathrm{Ca}^{2+}$-mediated mechanism does not contribute to the current occlusion.

The $I_{\mathrm{ACh}+\mathrm{ATP}}$ occlusion was observed at all negative holding potentials when the current was inward but was not observed for outward currents at a $V_{\mathrm{h}}$ of $+40 \mathrm{mV}$. Here the outward $I_{\mathrm{ACh}}+\mathrm{ATP}$ was not different from the predicted sum of $I_{\mathrm{ACh}}$ and $I_{\mathrm{ATP}}$ (Fig. 6B). The same dependence on current direction has been reported in guinea-pig enteric and submucosal neurons (Zhou and Galligan [20]; Barajas-Lopez et al. [21]), suggesting that the current occlusion was triggered by the inward movement of cations through two channels.

Some investigators have shown that the amplitude of $I_{\mathrm{ACh}+\mathrm{ATP}}$ is equal to or even smaller than that of either $I_{\mathrm{ACh}}$ or $I_{\mathrm{ATP}}$. For instance, the concentration of one agonist causing little or no inward current produced dramatic occlusion of the inward current generated by the other agonist (Searl et al. [19]). Khakh et al. [22] using Xenopus oocytes co-expressing $\mathrm{P} 2 \mathrm{X}_{2}$ and $\alpha 3 \beta 4 \mathrm{nAChR}$ channels, provided several lines of evidence which indicated that occlusion was mostly mediated by the inhibition of the nAChR channel by activation of the P2XR. However, we found that concomitant application of two agonists always caused a larger current than either agonist (Fig. 6A), and that the amount of occlusion of one 
channel current in the presence of the other channel agonist was correlated with the amplitude of current through the other channel (Fig. 4). Furthermore, we found that $I_{\mathrm{ACh}}+$ ATP desensitizes faster than $I_{\mathrm{ATP}}$, but more slowly than $I_{\mathrm{ACh}}$, and $I_{\mathrm{ACh}}+\mathrm{ATP}$ at a $V_{\mathrm{h}}$ between $E_{\mathrm{ACh}}$ and $E_{\mathrm{ATP}}$ showed a combination pattern of early outward $I_{\mathrm{ACh}}$ and delayed inward $I_{\mathrm{ATP}}$ (Fig. 6C). These results both strongly suggest that in AP neurons, $I_{\mathrm{ACh}+\mathrm{ATP}}$ are carried through both $\mathrm{nAChR}$ and P2XR channels, and that inhibition between these channels is reciprocal.

The $I_{\mathrm{ATP}}$ was not inhibited by co-application of ACh when the inward $I_{\mathrm{ACh}}$ was markedly reduced in the absence of permeant cations (Fig. 8B) or at a $V_{\mathrm{h}}$ very close to $E_{\mathrm{ACh}}$ (Fig. $8 \mathrm{D}$ ), and the inhibited $I_{\mathrm{ATP}}$ in the presence of ACh (Fig. 5B) recovered as soon as the nAChR channel closed in the presence of dTc (Fig. 5C). These results thus suggest that the inhibitory interaction not only requires the activation of both receptor channels, but also requires a substantial current to flow through these channels. These results are in contrast to that obtained in sympathetic neurons, in which the ATP-induced glucosamine influx was inhibited in the presence of ACh (Nakazawa [30]). The cause of this inconsistency remained unknown, but may reflect a real difference in the underlying mechanisms of occlusion in these two types of neurons.

Altogether, our results have characterized the P2XR responses in AP neurons and the cross-inhibition between P2XRs and nAChRs in AP neurons. We show that the current flow through one receptor channel hinders the current flow through the other channel. These interactions support the notion that these channels are positioned very close to each other, as has been previously considered (Zhou and Galligan [20]; Barajas-Lopez et al. [21]; Khakh et al. [22]; Boue-Grabot et al. [24]) and more recently demonstrated for recombinant channels (Khakh et al. [23]). These results will be important to consider when designing ligands to modify excitability of ATP neurons and may have some physiological function during co-activation of P2XRs and nAChRs by synaptically released transmitters.

\section{References}

1. Borison HL (1974) Area postrema: Chemoreceptor trigger zone for vomiting is that all? Life Sci 14:1807-1817

2. Borison HL (1984) History and status of the area postrema. Fed Proc 43:2937-2940
3. Franchini LF, Johnson AK, De Olmos J et al (2002) Sodium appetite and Fos activation in serotonergic neurons. Am J Physio 282:R235-243

4. Fink GD, Bruner CA, Mangiapane ML (1987) The area postrema is critical for angiotensin induced hypertension. Hypertension 9:355-361

5. Undesser KP, Hasser EM, Haywood JR et al (1985) Interactions of vasopressin with the area postrema in arterial baroreflex function in conscious rabbits. Circ Res 56:410-417

6. Morest DK (1967) Experimental study of the projections of the nucleus of the tractus solitarius and the area postrema in the cat. J Comp Neurol 130:277-299

7. Kooy VDD, Koda LY (1983) Organization of the projections of a cirumventricular organ: The area postrema in the rat. J Comp Neurol 219:328-338

8. Shapiro RE, Miselis RR (1985) The central neural connections of the area postrema of the rat. J Comp Neurol 234:344-364

9. Sun MK, Spyer KM (1991) GABA-mediated inhibition of medullary vasomotor neurons by area postrema stimulation in rats. J Physiol (Lond) 436:669-684

10. Papas S, Smith P, Furguson AV (1990) Electrophysiological evidence that systemic angiotensin influences rat area postrema neurons. Am J Physiol 258:R70-R76

11. Jahn K, Bufler J, Weindl A et al (1996) Patch-clamp study on membrane properties and transmitter activated currents of rabbit area postrema neurons. J Comp Physiol 178:771-778

12. Hay M, Lindsley KA (1999) AMPA receptor activation of area postrema neurons. Am J Physiol 276:R586-R590

13. Sorimachi M, Yamagami K, Wakamori M (2002) Expression of $\mathrm{P} 2 \mathrm{X}$ receptors on area postrema neurons of rat brain: Studies with fura-2 microfluorometry. Jpn J Physiol 52:suppl. s119

14. Sorimachi M, Yamagami K, Wakamori M (2003) ATPinduced current in area postrema neurons of rat brain: Possible expression of $\mathrm{P}_{2} \mathrm{X}_{2}$ receptor. Jpn J Physiol 53: suppl. s203

15. Funahashi M, Mitoh Y, Matsuo R (2002) Nicotinic modulation of area postrema neuronal excitability in rat brain slices. Brain Res 1017:227-233

16. Sorimachi M, Wakamori M (2005) Nicotinic ACh receptor in area postrema neurons of immature rat brain. Neurosci Lett 381:350-353

17. Akasu T, Koketsu K (1985) Effect of adenosine triphosphate on the sensitivity of the nicotinic acetylcholine-receptor in the bullfrog sympathetic ganglion cell. Brit J Pharmacol $84: 525-531$

18. Nakazawa K, Fujimori K, Takanaka A et al (1990) An ATPactivated conductance in pheochromocytoma cells and its suppression by extracellular calcium. J Physiol (Lond) 428:257-272

19. Searl TJ, Redman RS. Silinsky EM (1998) Mutual occlusion of P2X ATP receptors and nicotinic receptors on symapathetic neurons of the guinea-pig. J Physiol (Lond) 510:783791

20. Zhou X, Galligan JJ (1998) Non-additive interaction between nicotinic cholinergic and $\mathrm{P} 2 \mathrm{X}$ purine receptors in guinea-pig enteric neurons in culture. J Physiol (Lond) 513: 685-697.

21. Barajas-Lopez C, Espinosa-Luna R, Zhu Y (1998) Functional interactions between nicotinic and P2X channels in shortterm cultures of guinea-pig submucosal neurons. J Physiol (Lond) 513:671-683

22. Khakh BS, Zhou X, Sydes J et al (2000) State-dependent cross-inhibition between transmitter-gated cation channels. Nature 406:405-410

23. Khakh BS, Fisher JA, Nashmi R et al (2005) An angstrom scale interaction between plasma membrane ATP-gated 
P2X 2 and $\alpha_{4} \beta_{2}$ nicotinic channels measured with fluorescence resonance energy transfer and total internal reflection fluorescence microscopy. J Neurosci 25:6911-6920

24. Boue-Grabot E, Barajas-Lopez C, Chakfe Y et al (1984) Intracellular cross talk and physical interaction between two classes of neurotransmitter-gated channels. J Neurosci 15: 1246-1253

25. Lewis CA (1979) Ion-concentration dependence of the reversal potential and the single channel conductance of ion channels at the neuromuscular junction. J Physiol (Lond) 286: 417-445

26. Grynkiewicz G, Poenie M, Tsien RY (1985) A new generation of $\mathrm{Ca}^{2+}$ indicators with greatly improved fluorescence properties. J Biol Chem 260:3440-3450

27. Sorimachi M, Abe Y, Furukawa K et al (1995) Mechanism underlying the ATP-induced increase in the cytosolic $\mathrm{Ca}^{2+}$ concentration in chick ciliary ganglion neurons. J Neurochem 64:1169-1174

28. King BF, Ziganshina LE, Pintor J et al (1996) Full sensitivity of $\mathrm{P} 2 \mathrm{X} 2$ purinoceptor to ATP revealed by changing extracellular $\mathrm{pH}$. Br J Pharmacol 117:1371-1373

29. Hay M, Hasser EM, Lindsley KA (1996) Area postrema voltage-activated calcium currents. J Neurophysiol 75:133-141

30. Nakazawa K (1994) ATP-activated current and its interaction with acetylcholine-activated current in rat sympathetic neurons. J Neurosci 14:740-750

31. Manalis RS (1977) Voltage-dependent effect of curare at the frog neuromuscular junction. Nature 267:366-368

32. Grassi F, Polenzani L, Mileo AM et al (1993) Blockage of nicotinic acetylcholine receptors by 5-hydroxytryptamine. J Neurosci Res 34:562-570

33. Garcia-Colunga J, Miledi R (1995) Effects of serotonergic agents on neuronal nicotinic acetylcholine receptors. Proc Natl Acad Sci USA 92:2919-2923
34. Sorimachi M, Wakamori M (2004) Inhibitory effect of serotonin on ACh-induced currents in area postrema neurons of rat brain. Jpn J Physiol 54:suppl. s137

35. Fieber LA, Adams DJ (1991) Adenosine triphosphate-evoked currents in cultured neurons dissociated from rat parasympathetic cardiac ganglia. J Physiol (Lond) 434:239-256

36. Rogers M, Dani JA (1995) Comparison of quantitative calcium flux through NMDA, ATP and ACh receptor channels. Biophys J 68:501-506

37. Collo G, North RA, Kawashima E et al (1996) Cloning of $\mathrm{P} 2 \mathrm{X} 5$ and $\mathrm{P} 2 \mathrm{X} 6$ receptors and the distribution and properties of an extended family of ATP-gated ion channels. J Neurosci 16:2495-2507

38. Kanjhan R, Housley GD, Burton LD et al (1999) Distribution of the P2X2 receptor subunit of the ATP-gated ion channels in the rat central nervous system. J Comp Neurol 407:11-32

39. Atkinson L, Batten TF, Deuchars J (2000) $\mathrm{P} 2 \mathrm{X}_{2}$ receptor immunoreactivity in the dorsal vagal complex and area postrema of the rat. Neuroscience 99:683-696

40. Krishtal OA, Marchenko SM, Obukhov AG (1988) Cationic channels activated by extracellular ATP in rat sensory neutons. Neuroscience 27:995-1000

41. Sorimachi M, Ishibashi H, Moritoyo T et al (2001) Excitatory effect of ATP on acutely dissociated ventromedial hypothalamic neurons of the rat. Neuroscience 105: 393-401

42. Evans RJ, Lewis C, Virginio C et al (1996) Ionic permeability of, and divalent cation effects on, two ATP-gated cation channels ( $\mathrm{P} 2 \mathrm{X}$ receptors) expressed in mammalian cells. J Physiol (Lond) 497:413-422

43. Virginio C, North RA, Surprenant A (1998) Calcium permeability and block at homomeric and heteromeric P2X2 and $\mathrm{P} 2 \mathrm{X} 3$ receptors, and $\mathrm{P} 2 \mathrm{X}$ receptors in rat nodose neurones. J Physiol (Lond) 510:27-35 